\title{
YADNYA DALAM BINGKAI RITUAL DAN POLITIK
}

\author{
Oleh : I Nyoman Suamba
}

\begin{abstract}
This article discusses the problem of yajna in its implementation into various rituals whose existence often comes into contact with politics. Implementation is often identified with ceremonies or rituals, even though the scope of the real yajna is broader in scope. Lontar-lontar as a ritual reference text also more explicitly mentions yajna as a ritual form that contains offerings and worship. Hindus in Bali recognize the Panca Yajna that emerged from the principle of Tri Rna. In the implementation of the Panca Yajna, especially the yajna which are general or together in nature, for example those held by Desa Pakraman and other groups, as well as the yajna in the temple, often involve political participation in their implementation. One example is the provision of assistance to every Desa Pakraman in Bali by the Bali Government as a form of political participation in the implementation of the Yajna. Likewise with the emergence of the simakrama phenomenon of political figures when the implementation of the yajna is a form of intersection between political activity and religious activities. This will be discussed in this article.
\end{abstract}

Keywords: yajna, ritual, and politics.

\section{Pendahuluan}

Secara etimologi kata yajna merupakan bahasa Sanskerta, yaitu berasal dari urat kata yaj yang berarti pengorbanan dengan penuh cinta kasih. Bersumber dari akar kata tersebut kemudian berkembang menjadi beberapa istilah, antara lain yajna, yajus, dan yajamana. Kata yajna itu sendiri berarti pemujaan, persembahan atau korban suci. Kata yajus artinya aturan-aturan tentang yajna, sedangkan yajamana merupakan salah satu unsur dari yang disebut tri manggalaning yajna, yaitu tiga unsure penting dalam pelaksanaan yajna yang terdiri dari tiga unsur, yaitu (1) orang yang memimpin upacara tersebut (pemuput); (2) orang yang membuat sesajen (tapini yajna); dan (3) orang yang melaksanakan yajna atau sang yajamana (Tim, 2011: 607).

Pelaksanaan yajna bersumber dari kitab Rgveda X.90.6 yang menyebutkan sebagai berikut:

Yat purusena havisa devayajnam atanvatanya

Vasanto asyasid ajyam grisma idmah saraddhavih 


\section{Terjemahan:}

Ketika para dewa mengadakan upacara korban dengan purusa sebagai persembahan, maka minyaknya adalah musim semi, kayu bakarnya adalah musim panas, dan sesajen persembahannya adalah musim gugur.

Demikian juga dalam Bhagavadgita III. 10-11 menyebutkan sebagai berikut:

Saha yajnah prajah srstva

Puro 'vacha prajapatih

anena prasavishya dhvam

esa vo'stv ishta kamadhuk

\section{Terjemahan:}

Dahulukala Prajapati menciptakan manusia bersama bakti persembahannya dan berkata: dengan ini engkau akan berkembang biak dan biarlah ini jadi sapi perahanmu.

\section{Devan bhavayata nena}

Te deva bhavayantuvah

Parasparan bhavayantah

Sreyah param avapsyatha

\section{Terjemahan:}

Dengan ini (yajna), pujalah dewata Semoga dewata memberkahi engkau Dengan saling menghormati begini Engkau mencapai kebajikan tertinggi (Pendit, 1991 : 82-83).

Berdasarkan sloka dalam Bhagavadgita di atas disebutkan manusia diciptakan melalui yajna oleh Prajapati, dan melalui yajna manusia dijanjikan dapat mencapai segala keinginannya. Selain untuk memenuhi keinginan, yajna juga diamanatkan sebagai bentuk penghormatan kepada dewata, karena melalui yajna manusia memberikan penghormatan kepada dewata, dan kemudian para dewata akan memberkahi manusia. Bhagavadgita III. 11 memberikan penegasan bahwa manusia diwajibkan untuk melakukan yajna sebagai bentuk saling menghormati (balas budi) kepada para dewata yang telah menciptakan dan memelihara manusia. Dengan amanat tersebut dapat dikatakan bahwa yajna merupakan bentuk membayar hutang kepada pihak-pihak yang telah menyelenggarakan kehidupan ini. Team Penyusun (1995: 10) menyebutkan hutang itu disebut Tri Rna, yaitu tiga macam jenis hutang yang wajib dibayar oleh manusia. Adapun tiga jenis hutang tersebut meliputi:

1. Dewa Rna, yaitu hutang yang ada dan harus dibayar kepada Tuhan dan manifestasNya. Hutang ini muncul, karena manusia berhutang kepada Tuhan yang telah menciptakan umat manusia, baik berupa badan jasmani maupun memberikan unsur kehidupan dalam bentuk atman yang menyatu dalam badan.

2. Rsi Rna adalah hutang yang harus dibayar kepada para rsi sebagai penerima wahyu suci, para pandita dan para guru yang telah memberikan pengetahuan, sehingga manusia menjadi insan yang berilmu dan memahami akan hakikat jadi dirinya. Atas jasa-jasa para rsi memberikan pengetahuan agung tersebut, maka manusia wajib membayarnya melalui yajna.

3. Pitra Rna adalah hutang kepada para leluhur dan orang tua, sebab melalui beliau manusia mendapatkan badan manusianya, sehingga atman dapat memasuki badan yang telah terbentuk. Atas jasa para leluhur 
dan orang tua yang menjadikan manusia hadir di muka bumi ini, maka sebagai bentuk kewajiban religius, manusia harus membayar hutang tersebut.

Dalam aplikasinya yajna lebih sering diidentikkan dengan ritual. Tim (2011: 4900 menyebutkan ritual merupakan suatu representasi sikap dan emosi religius masingmasing dari agama/kepercayaan yang dianutnya. Representasi yang demikian merupakan sesuatu yang wajar, karena merupakan salah satu aspek pemahaman dari konsep korban suci yang berdimensi vertikal (kepada Sang Pencipta) ataupun horizontal (sesama umat). Sistem ritual yang direpresentasikan penganut agama/ kepercayaan tertentu dapat menbjadi media saling mengerti, timbang wirasa, silaturahmi baik secara intern maupun ekstern.

Umat Hindu yang hidup dalam bingkai Negara Kesatuan Republik Indonesia (NKRI) tidak dapat lepas dari ikatan hukum dan perundang-undangan serta berbagai kebijkan pemerintah. Berbagai kebijakan yang ditetapkan oleh pemerintah di dalam menata dan membina masyarakatnya termasuk warga negaranya yang beragama Hindu sudah tentu merupakan bentuk campur tangan politik dalam kehidupan beragama. Hal ini tidak dapat dipungkiri, sehingga aktivitas keagamaan (Hindu) termasuk di dalamnya aktivitas yajna terutama dalam arti ritual yang diselenggarakan secara umum sering berkaitan dengan hal-hal politik. Wibawa (2003: 13) menyebutkan, pemerintah yang identik dengan kekuasaan haruslah orang yang memiliki kualitas moral, prinsip-prinsip politik yang benar. Konsep dharma Negara dan dharma agama sebagai basis perilaku ketatanegaraan Indonesia yang berdasarkan pancasila. Pemerintah wajib memiliki ketiga wawasan ini (Politik, Ekonomi, dan Agama).

\section{P EMBAHASAN}

Berdasarkan Tri Rna sebagaimana disebutkan sebelmunya, maka lahirlah berbagai bentuk yajna sesuai dengan tujuan yang hendak diberi persembahan. Agastya Parwa menyebutkan lima jenis yajna atau Panca Maha Yajna yang muncul dari Tri Rna tersebut, sedangkan dalam teks Kala Tattwa disebutkan ada tujuh jenis yajna (Sapta yajna). Kitab Agastya Parwa menyebutkan sebagai berikut:

Kunang ikang yajna lima pratyekanya, lwirnya : dewayajna, rsiyajna, pitrayajna, bhutayajna, manusa-yajna, nahan tang panca yajna ring loka. Dewayajna ngaranya taila pwa krama ri bhattara Sivagni, makagelaran ing maniala ring bhattara; yeka dewayajna ngaranya. Rsiyajna ngaranya kapujan sang pandita mwang sang wruh ri kalingan ing dadiwwang; ya rsiyajna ngaranya. Pitrayajna ngaranya tileman bwat hyang Sivasraddha; yeka pitrayajna ngaranya. Bhutayajna ngaranya tawur mwang kapujan ing tuwuh ada pamunwan kunai wulan makadi walikrama, ekadasadewata-maniala; ya bhutayajna ngaranya. Manusayajna ngaranya maweh apangan ring kraman. Ika ta limang wiji ri sedan ning lokacara mangabhayasa ika makabheda lima.

\section{Terjemahan:}

Yajna itu lima jenisnya, yaitu dewayajna, rsiyajna, pitrayajna, manusayajna, 
dan bhutayajna. Itulah Panca Yajna di masyarakat. Dewa yajna adalah persembahan minyak kepada Bhatara Siwagni yang disthanakan di tempat bhatara. Itulah yang disebut dewayajna. Rsiyajna adalah penghormatan kepada para pandita dan orang yang mengetahui hakikat kelahiran menjadi manusia. Itulah rsiyajna. Pitrayajna adalah upacara kematian yang dipersembahkan kepada Siwa sebagai penguasa upacara kematian. Itulah pitrayajna. Bhutayajna adalah tawur dan penghormatan kepada sarwa bhuta pamungwan,tempat api pemujaan, wulan, terutama walikrama, wilayah dewadewa yang sebelas. Itulah bhutayajna. Manusayajna ialah memberikan makanan kepada masyarakat.Itulah lima jenis upacara yang umum dilaksanakan oleh masyarakat.

Sementara itu dalam teks Kala Tattwa (dalam Suwadnyana, Maret 2012 : 37-38) disebutkan manfaat dari Sapta Yajna atau tujuh jenis yajna yang manfaatnya masing-masing yajna sebagai berikut:

Gunaning manusa yajna magawe kateguhan ing jagat, mwang langgeng nira Sang Pradipati rumaksa jagat.

\section{Terjemahan:}

Manusa yajna berguna untuk menjadikan kokohnya Negara dan kekalnya sang pemimpin yang menguasai Negara.

Kunang ikang bhuta yajna maka ngaran ing tuwur, kweh pratingkahnia agung alit sarupa ning tawur ya bhuta yajna juga nga. Ika maka tadahe kita paring lan wadwa kala ta makabehan, apan tawur maka sasilih awak ira sang adrewa caru apan panawar danda ning sudosan ipun, twin kadurmitan kaupadrawan lawan kadurmanggalanira prasiddha ning pamidandanira, agung alit tuten ira pwa den ta.

\section{Terjemahan:}

Adapun Buta Yajna itu adalah tawur. Beragam bentuknya, besar-kecil tawur itu juga Bhuta Yajna namanya. Itu menjadi santapan para kala bersama rakyatnya, oleh karena itu tawur sebagai kurban orang yang menyelenggarakan caru, sebagai pembebas hukuman orang yang berdosa ataupun orang yang memperoleh pertanda buruk, malapetaka, dan isyarat yang kurang baik, tawur itu dapat menghilangkan hukuman yang besar dan kecil, karena itu patut dilaksanakan.

Resi yajna ilang ning papapataka nira sang awangun Resi Yajna, teka katekang papa gati sangsara ning kawitan ira. Mangkana pwa ya, mapan wus kaparisuddha, dening watek resinggana makabehan.

\section{Terjemahan:}

Resi Yajna akan melenyapkan segala dosa dan kemalangan orang yang beryajna sampai dengan lima bentuk kesengsaraan leluhurnya. Demikianlah pahalanya, oleh karena telah disucikan oleh para resi seluruhnya.

Samangkana pratekan ing sawa aweha mukti swarga sang dewa pitara, apan hana dosanya nguni du king kari mahurip ring Madhya pada, mangke ring Yama ning 
loka tinemnya sangsara dinenda denira watek kingkara bhuta, karananing hana wenang tinebas dening pengaci-aci manut sakramanira puja pitra de ning Pitra Yajna maka prasiddha ning sang atma mantuk ing swarga loka.

\section{Terjemahan:}

Demikianlah upacara terhadap jenazah memberikan sang dewa pitara (leluhur) untuk menikmati sorga, oleh karena ada dosanya pada waktu masih hidup di dunia, makanya sekarang menerima penderitaan di neraka dihukum oleh Sang Hyang Yama Dipati, dihukum oleh para Bhuta Kingkara. Itu yang menyebabkan patut ditebus dengan suatu upacara sesuai dengan tatacara memuja pitra (leluhur) dengan Pitra Yajna sebagai sarana agar sang atma dapat kembali ke sorga.

Dewa yajna maka pangilanga papa-klesa, panyadmaya mwang kadurmitanya ring loka, agung alit ikang yajna, magawe kapagehan ing Sang Hyang Pramana makadi Sang Hyang Urip ring bhuwana kabeh, apan langgeng yoga nira dening dewata kabeh ngamredyaken ayuning jagat raya. Mangkana kengetakena.

\section{Terjemahan:}

Dewa Yajna sebagai penghapus papa penderitaan, baik yang dibawa sejak lahir maupun kemalangannya dalam hidup di dunia ini. Besar kecil upacara itu juga Dewa Yajna namanya, menyabebkan kekalnya sang hyang atma maupun semua makhluk hidup di bumi, oleh karena langgengnya yoga para dewata yang menyebabkan bertambahnya kebaikan dunia. Karena itu ingatlah selalu.
Kunang guna ning Asiwa Yajna, apan yajna ring mami Hyang Siwa-pati likansana de ning wang dredha bhakti ring guru, ya ta umilangaken papa pataka lemeh ing sariranya kabeh luluh temahanya.

\section{Terjemahan:}

Adapun manfaat dari Siwa Yajna, karena yajna itu ditujukan untuk Sang Hyang Siwapati yang dilaksanakan oleh orang yang setia kepada guru. Hal itu akan menghilangkan papa dan penderitaan, serta menyebabkan leburnya kebencian di dalam diri.

Gunaning Aswameda Yajna kawruhaken denta anakku, ikang yajna angentasaken saisin rat bhawana.

\section{Terjemahan:}

Guna dari Aswameda Yajna, ketahuilah olehmu anakku, yajna itu untuk menyucikan seluruh isi dunia.

Yajna pada kenyataannya selalu disertai dengan persembahyangan, pemujaan, pengorbanan, pengabdian, kebaktian, permohonan berkah, restu, puji syukur, pasrah diri dan sebagainya. Ini banyak tergantung kepada yang melaksanakannya dan yang memimpin pelaksanannya, juga dalam konteks apa suatu yadnya dilaksanakan dan jenis mana yang patut dan cocok baginya (Setia, 1992: 48). Selain itu yajna yang diaplikasikan ke dalam bentuk ritual dipandang oleh Negara sebagai sarana untuk membangun Sumber Daya Manusia warganya, oleh karena itu aktivitas yajna dengan ritual ini pun mendapat perhatian dan alokasi kebijakan oleh Negara. Salah satu contohnya adalah kebijakan Pemerintah Provinsi Bali 
yang memberikan bantuan dana ke setiap desa pakraman di seluruh Bali untuk membangun SDM melalui aktivitas keagamaan yang tentu di dalamnya termasuk ketentuan penggunaan dana bantuan tersebut untuk membangun atau merawat tempat suci, dan kegiatan penunjangnya. Kebijakan ini jelas merupakan bentuk intervensi politik kenegaraan ke dalam ranah kehidupan agama masyarakat.

Pada tahun 2018 Pemerintah Provinsi Bali memberikan Bantuan Keuangan Khusus (BKK) kepada 1488 desa pakraman se Bali dengan nominal masing-masing desa pakraman sejumlah Rp 225 juta. Dari jumlah tersebut ritual upacara yang menjadi kebutuhan riil warga harus dibantu lewat BKK, di samping dimanfaatkan dalam pembentukan pasraman untuk meningkatkan pemahaman generasi muda mengenai adat dan budaya (bali. antaranews.com).

Perhatian Negara sebagai institusi politik yang berkepentingan mengatur kehidupan warganya memandang aktivitas keagamaan masyarakat sebagai suatu aspek sosial budaya sangat berpengaruh terhadap keberhasilan proses pembangunan. Damsar (2015: 146) menyebutkan, struktur sosial budaya masyarakat memainkan peranan tidak kalah pentingnya dalam pembentukan keberhasilan atau kegagalan suatu pembangunan. Orang dalam bertindak selalu meorientasikan tindakannya terhadap tingkah laku orang lain melalui makna yang dikonstruksi secara sosial. Orang menginterpretasikan (verstehen) adat, kebiasaan, norma, dan kepentingan yang mereka miliki dalam hubungan social yang sedang berlangsung. Selain itu Wiana (2006: 45) menegaskan, untuk membangun masyarakat sejahtera dicapai dengan menerapkan Catur Vidya, yaitu: Anviksaki yang berarti menyatukan persepsi dan visi untuk dirumuskan menjadi satu ideology atau citacita bersama untuk membangun kesejahteraan masyarakat. Vedatrayi, yaitu penerapan ajaran suci Veda untuk membangun moral. Membangun kesejahteraan tanpa dilandasi oleh moral yang kuat hanya akan menimbulkan kesengsaraan. Vartta, yaitu membangun basis ekonomi dengan pertanian (krsi), peternakan (goraksya), dan perdagangan (vanijyam). Danda Niti, yaitu sistem hukum yang mampu mengatur dan mengendalikan berbagai sumber daya untuk terselenggaranya kegiatan yang mendukung terwujudnya masyarakat sejahtera.

Melalui cara pandang seperti itu, maka perhatian secara politik oleh pemerintah terhadap kehidupan beragama termasuk dalam yajna merupakan sebuah keniscayaan untuk mewujudkan kehidupan masyarakat yang harmonis secara holistik. Sebagaimana dinyatakan Malefijt (dalam Agus, 2006: 5) bahwa agama adalah the most important aspects of culture yang dipelajari oleh ahli antropologi dan ilmuwan sosial lainnya. Aspek kehidupan beragama tidak hanya ditemukan dalam setiap masyarakat, tetapi juga berinteraksi secara signifikan dengan institusi budaya yang lain. Ekspresi religius ditemukan dalam budaya material perilaku manusia, nilai, moral, system keluarga, ekonomi, hokum, politik, pengobatan, sains, teknologi, seni, pemberontakan, perang, dan lain-lain.

Hubungan antara agama dan politik (penguasa) merupakan ikatan yang saling membutuhkan dan saling memanfaatkan. Para penganut agama membutuhkan perlindungan 
dari penguasa, sebagaimana halnya agamaagama di Indonesia dijamin eksistensi dan aktivitasnya berdasarkan undang-undang, yaitu Pasal 28E ayat (1) Undang-Undang Dasar Tahun 1945 (UUD 1945). Pasal 28E ayat (2) UUD 1945 juga menyatakan bahwa setiap orang berhak atas kebebasan meyakini kepercayaan. Selain itu dalam Pasal 281 ayat (1) UUD 1945 juga diakui bahwa hak untuk beragama merupakan hak asasi manusia. Selanjutnya Pasal 29 ayat (2) UUD 1945 menyatakan bahwa negara menjamin kemerdekaan tiap-tiap penduduknya untuk memeluk agama.

PadaabadXRajaUdayanayangmemerintah Bali memprakarsai adanya reunifikasi sektesekte keagamaan dengan mendatangkan Mpu Kuturan dari Jawa untuk melaksanakan proyek besar itu. Peristiwa tersebut merupakan bentuk hegemoni politik terhadap kehidupan beragama terbesar yang pernah dicatat dalam sejarah Bali. Tindakan Raja Udayana tersebut bertujuan untuk menciptakan ketertiban di wilayah kekuasaannya mengingat konflik sektesekte keagamaan yang menajam di zaman itu. Dengan demikian dapat dikatakan penguasa membutuhkan ketenteraman wilayahnya, sementara itu pemeluk agama membutuhkan perlindungan politik dari penguasa, agar dapat bebas melakukan aktivitas agamanya.

Hubungan antara politik dan agama juga berlangsung dalam kehidupan modern masa kini. Dalam berbagai kegiatan keagamaan, terutama pelaksanaan yajna berupa ritual keagamaan, maka sering dihadiri para politisi dalam bingkai slogan "simakrama." Pada pelaksanaan Piodalan, upacara Ngenteg Linggih, Ngaben bersama, dan lain-lain sering dihadiri pejabat pemerintah (gubernur, bupati/ walikota) ataupun politisi yang ingin mendapat dukungan suara dari masyarakat sekitar pekaksanaan yajna itu. Saat hadir dalam hajatan ritual tersebut sering para politisi yang hadir tersebut memberikan sumbangan atau dana punia, sementara itu kalau pejabat yang hadir umumnya disertai penyerahan bantuan sosial (bansos). Dengan demikian, melalui acara ritual tersebut para politisi memanfaatkan momentum tersebut untuk mendekatkan dirinya dengan masyarakat yang nantinya merupakan voter (pemilih) atau pemilik hak suara dalam pemilu dan sangat berharap usaha pendekatannya ini mampu menarik simpati masyarakat. Sementara itu umat Hindu yang menggelar ritual (yajna) juga merasa diuntungkan oleh kehadiran para pejabat maupun politisi itu, karena disertai membawa sumbangan yang akan meringankan biaya ritual.

Keterkaitan politik dengab pelaksanaan yajna tidak dapat dihindarkan, sebagaimana Manava Dharmasastra XII-Santi Parwa LXII menyebutkan: "Manakala politik telah sirna, Veda pun sirna, semua aturan hidup musnah, semua kewajiban manusia terabaikan, pada politik semua berlindung, pada politik semua awal tindakan diwujudkan, pada politik semua pengetahuan dipersatukan dan pada politik semua dunia terpusatkan (Wibawa, 2003: 11). Hal ini dimaksudkan bahwa kesejahteraan masyarakat tidak bakalan terwujud bila situasi politik pemerintahan Negara tidak memungkinkan untuk terjadinya harmonisasi, karena landasan agama juga menjadi amburadul.

Interaksi politik dan agama melalui peristiwa ritual keagamaan akan bermakna positif bila ditinjau dari sudut pandang kepentingan menciptakan ketenteraman dan 
ketertiban, karena akan terbangun komunikasi yang baik antara politisi atau pejabat pemerintah dengan masyarakat. Budiardjo (dalam Damsar, 2015: 208) menyebutkan komunikasi politik merupakan fungsi sosialisasi politik dan budaya politik. Komunikasi yang berjalan baik menjadi prasyarat sosialisasi politik untuk dapat berjalan dengan baik pula, sehingga budaya politik dapat dilangsungkan dengan baik. Sementara itu Pratama (dalam rohmanfikomjayabaya. blogspot.com) Menyebutkan saluran komunikasi politik, yakni komunikasi massa, yaitu komunikasi yang dilakukan oleh satu kepada banyak orang, contohnya komunikasi melalui media massa. Komunikasi tatap muka, yaitu komunikasi yang menggunakan sarana tatap muka langsung maupun penghubung. Komunikasi interpersonal, yaitu komunikasi yang dilakukan oleh orang perorang, seperti menemui publik atau konstituen atau komunikasi organisasi, yaitu gabungan komunikasi massa dengan tatap muka.

Berdasarkan hal tersebut aktivitas ritual keagamaan dijadikan sebagai salah satu ajang tempat diadakannya komunikasi politik secara tatap muka oleh para politisi maupun pejabat pemerintah. Simakrama politik model ini dinilai efektif karena saat penyelenggaraan ritual umumnya banyak orang yang hadir, sehingga para politisi dapat bertemu dengan banyak orang tanpa harus secara sengaja mengumpulkan orang-orang melalui undangan khusus. Penyelenggaraan ritual yang penuh nuansa tradisional juga menjadikan kehadiran politisi maupun pejabat pemerintah saat ajang tersebut tidak terkesan formal, karena hadir sebagai undangan untuk menghadiri upacara, bukan undangan sebagai tokoh politik. Hal ini sekaligus menghindari kesan terjadinya politisasi ritual keagamaan untuk memobilisasi massa memberikan dukungan politik terhadap figur tertentu.

Banyak kalangan berpendapat bahwa antara persoalan ekonomi, politik, dan agama yang satu dengan yang lainnya tidak memiliki keterkaitan, sama sekali tidak ada korelasi. Namun demikian, jika bidang-bidang kehidupan masyarakat yang bernaung di bawah suatu Negara berjalan sendiri-sendiri tanpa koordinasi yang tegas dari pemerintah, maka niscaya akan sulit tercapai suatu kehidupan yang tenteram dan harmonis. Masing-masing sektor, seperti politik, ekonomi, sosial, dan juga agama tidak ingin berhubungan dan bekerjasama dengan sektor lain, sehingga hal tersebut menciptakan ego sektoral dan situasi masyarakat akan kacau. Oleh karena itu yajna yang diimplementasikan dalam bentuk ritual senantiasa akan berada dalam bingkai politik, terutama politik dalam pengertian negara.

Negara adalah suatu organisasi dalam suatu wilayah yang mempunyai kekuasaan tertinggi yang sah dan ditaati rakyatnya. Selain itu negara dapat disebut sebagai sebuah integrasi kekuatan politik yang ada dalam masyarakat. Pada posisi itu, maka negara adalah menjadi agen bagi proses pelaksanaan kepentingan politik, atau aspirasi masyarakat (https://www. padamu.net). Oleh karena itu persentuhan politik di bidang keagamaan khususnya ritual keagamaan tidak dipandang sematamata sebagai bentuk memperalat aktivitas keagamaan demi keuntungan politik, tetapi interaksi tersebut juga sebagai cara efektif bagi politisi maupun pemerintah untuk menyerap aspirasi masyarakat. 


\section{KESIMPULAN}

Yajna merupakan suatu bentuk pengorbanan tulus ikhlas dalam spirit keagamaan yang dapat diimplementasikan melalui banyak cara, di antaranya dengan penyelenggaraan ritual. Ritual membuat pelaksanaan yajna menjadi terkesan khusus dan semarak, karena selain mengandung aktivitas pemujaan dan persembahan ke hadapan dewadewa, aktivitas ritual umumnya dihadiri banyak orang yang hadir sebagai saksi maupun turut membantu penyelenggaraan ritual. Melalui ritual masyarakat membangun kehidupan rohaninya dengan harapan kemudian terbentuk realitas kehidupan yang lebih baik. Oleh karena itu pemerintah memandang penting untuk memperhatikan dan memberikan dukungan terhadap kegiatan keagamaan, termasuk dalam hal beryajna atau melakukan ritual. Dukungan politik negara terhadap kehidupan beragama, khususnya saat ritual kemudian diikuti pula oleh kehadiran para politisi pada momentummomentum tersebut. Kehadiran tokoh-tokoh politik pada ajang seperti itu akan bermanfaat secara positif apabila kesempatan tersebut digunakan sebagai upaya menyerap aspirasi masyarakat, karena banyak orang berkumpul pada momentuk tersebut. Sebaliknya, simakrama politik semacam itu akan berdampak negatif bagi kehidupan beragama apabila tercipta suatu tautan hegemoni, misalnya masyarakat terhegemoni oleh tokoh-tokoh politik, karena ikatan bantuan-bantuan material dan lainnya yang diberikan pada saat kegiatan ritual maupun yajna lainnya. Oleh sebab itu masyarakat perlu semakin melek dalam pendidikan politik untuk menghindari politisasi yajna dan ritual yang dapat mengakibatkan ketidakseimbangan kehidupan di tengah masyarakat sebagai akibat terlalu dominannya politik terhadap bidang kehidupan lainnya.

\section{DAFTAR PUSTAKA}

Damsar, Prof. Dr., 2015. Pengantar Sosiologi Politik. Jakarta: Prenamedia Grup.

Pendit, Nyoman S., 1992. "Kewajiban Kita Mempersembahkan Yadnya," dalam Putu Setia (editor). Cendekiawan Hindu Bicara. Jakarta: Yayasan Dharma Naradha.

Suwadnyana, I Wayan, 2012. "Ajaran Siwaistis dalam Teks Kala Tattwa," dalam Vidya Duta Volume V No. 2, Maret 2012. Denpasar : Jurusan Penerangan Agama, Fakultas Dharma Duta Institut Hindu Dharma Negeri Denpasar.

Tim Penyusun, 2011. Ensiklopedi Hindu. Surabaya: Penerbit Paramita

Team Penyusun, 2001. Panca Yadnya. Denpasar: Proyek Peningkatan Sarana dan Prasarana Kehidupan Beragama Tersebar di 9 (Sembilan) Kabupaten/Kota.

Wiana, Drs. I Ketut., 2006. Berbisnis Menurut Agama Hindu. Surabaya: Paramita.

Wibawa, Aripta. 2003. Butir-Butir Reformasi Hindu ke Depan. Denpasar: Deva.

https://www.padamu.net. Diakses 20 Agusrtus 2018.

rohmanfikomjayabaya.blogspot.com. Diakses 22 Agustus 2018. 